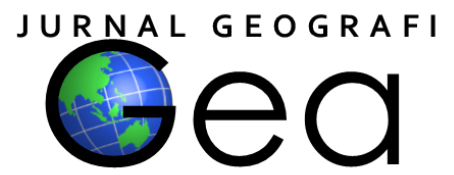

\title{
UPAYA KONSERVASI ELANG BONDOL DI PULAU KOTOK, TAMAN NASIONAL KEPULAUAN SERIBU, PROVINSI DKI JAKARTA
}

\author{
Naafila Noor Danica1, Siti Ita Murtajiah², Ode Sofyan Hardi ${ }^{3}$ \\ 1,2,3Prodi Pendidikan Geografi, Universitas Negeri Jakarta \\ 1naafila.danica@gmail.com, 2sitiitam@gmail.com
}

\begin{abstract}
This study aims to analyze eagle conservation efforts on Kotok Island, Thousand Islands National Park. Kotok Island is one of the islands in the Thousand Islands group. There is captivity and rehabilitation of the bondol eagle that is already rare on Kotok Island. The purpose of this study was to find out the history of the rescue and rehabilitation program of the bondol eagle on the island of Kotok, the conservation and rehabilitation efforts of the Bondol eagle, and the condition of the bonded eagle on Kotok Island today. The data collection method of this study is a descriptive analytic method. The conclusion of this study is that the bondol eagle which is the mascot of the city of DKI Jakarta is currently on the verge of extinction. Rehabilitation of eagles is not as easy as we imagine, because in the rehabilitation process not all of these eagles can be released again. We should cultivate awareness and understanding of the importance of preserving Indonesian animals, one of them is bondol eagles.
\end{abstract}

Keywords: bondol eagle, conservation, kotok island

\begin{abstract}
ABSTRAK
Penelitian ini bertujuan untuk menganalisis upaya konservasi elang di Pulau Kotok, Taman Nasional Kepulauan Seribu. Pulau Kotok merupakan salah satu pulau yang berada pada gugusan Kepulauan Seribu. Terdapat penangkaran dan rehabilitasi elang bondol yang sudah langka di Pulau Kotok. Tujuan dari penelitian ini adalah untuk mengetahui sejarah program penyelamatan dan rehabilitasi elang bondol di pulau kotok, upaya konservasi dan rehabilitasi elang bondol, dan kondisi elang bondol di Pulau Kotok saat ini. Metode pengambilan data penelitian ini berupa metode deskriptif analitik. Kesimpulan dari penelitian ini adalah elang bondol yang merupakan maskot kota DKI Jakarta saat ini sedang berada diambang kepunahan. Rehabilitasi elang tidak semudah yang kita bayangkan, karena dalam proses rehabilitasi tidak semua elang tersebut dapat dilepas liarkan kembali. Sudah seharusnya kita menumbuhkan kesadaran dan pemahaman akan pentingnya menjaga pelestarian satwa Indonesia, salah satuya elang bondol. .
\end{abstract}

Kata kunci : elang bondol, konservasi, pulau kotok.

\section{PENDAHULUAN}

Pulau Kotok merupakan salah satu pulau yang berada pada gugusan Kepulauan Seribu. Pulau Kotok termasuk ke dalam pulau paling utara dari Jakarta. Pulau Kotok merupakan contoh pulau atoll tropis dengan alam yang masih asli, laut yang jernih dan formasi batu karang berwarna-warni sehingga menjadi tujuan utama para penyelam.Pulau Kotok tidak bisa dikunjungi secara umum seperti pulaupulau lainnya yang dijadikan sebagai tempat pemukiman penduduk. Selain terdapat sebuah resort, di pulau yang sama terdapat sebuah penangkaran berbagai jenis burung elang, salah satunya elang bondol yang merupakan maskot kota DKI Jakarta. 
Dengan menyaksikan elang bondol yang terdapat di Pulau Kotok maka dapat memberikan pemahaman betapa pentingnya melestarikan alam Indonesia. Elang bondol yang sedang berada diambang kepunahan seakan memberi wawasan kepada Anda untuk selalu menjaga pelestarian lingkungan bumi Indonesia.

Elang merupakan burung pemangsa dalam puncak piramida makanan yang keberadaannya sangat penting dalam suatu ekosistem alam. Saat ini kehidupan burung elang dalam keadaan terdesak akibat berbagai ancaman yaitu hilangnya habitat akibat perubahan penggunaan lahan dan perburuan yang disebabkan tingginya permintaan untuk peliharaan. Jenis-jenis burung elang yang banyak menjadi incaran perburuan diantaranya adalah elang bondol (Haliastur Indus Boddaert, 1783) dan elang-laut perut-putih (Haliaeetus leucogaste Gmelin, 1788r). Jenisjenis elang tersebut dilindungi oleh UndangUndang RI no.5 tahun 1990 dan.tercantum dalam lampiran Peraturan Pemerintah RI no.7 tahun 1999. Berdasarkan IUCN 2014, elang bondol dan elang-laut perut-putih dikategorikan least concern (resiko rendah) dan elang-ikan kepala-abu (Ichthyophaga ichthyaetus Horsfield, 1821) dikategorikan near threatened (hampir terancam).

Elang Bondol (Haliastur Indus Boddaert, 1783) termasuk salah satu jenis burung pemangsa yang memiliki wilayah penyebaran luas. Spesies ini dapat ditemukan di Sri Lanka, Nepal, India, Pakistan, Bangladesh, Asia Tenggara,Cina dan Australia. Di Indonesia penyebaran elang bondol dapat dijumpai diKalimantan, Sumatera, Maluku, Papua, Sulawesi dan Nusa Tenggara. Secara global diperkirakan populasinya sekitar 100.000 individu dan di Asia tenggara populasinya terus mengalami penurunan (Ferguson-lees dan Christie 2001). Di Indonesia khususnya Pulau Jawa, keberadaan elang bondol juga mengalami penurunan populasi sangat drastis dan terancam punah (van Balen et al. 1993). Di Indonesia satwa ini dilindungi oleh Undangundang Nomor 5 tahun 1990, Peraturan Pemerintah Nomor 7 tahun 1999 dan Peraturan Pemerintah No. 421/Kpts/Um/8/8/1970 yang mengatur perlindungan semua jenis burung raptor diurnal.

Program penyelamatan dan rehabilitasi elang berlokasi di Pulau Kotok Besar berada di zona pemanfataan wisata Taman Nasional Kepulauan Seribu (TNKpS) dengan luas daratan sekitar 20,75 hektar. Program ini mulai pada tahun 2004, di resmikan oleh Menteri Kehutanan MS. Kaban, pada tanggal 8 Agustus 2005. Tahun 2016 pusat rehabilitasi elang bondol berubah menjadi pengelolaan pusat pengembangbiakan dan suaka satwa liar (sanctuary) dengan tujuan untuk meningkatkan populasi elang bondol serta jenis elang lainnya di TNKpS. Terselenggaranya program ini diinisiasi oleh Pusat Penyelamatan Satwa (PPS) Tegal Alur, kemudian di lanjutkan oleh International Animal Rescue (IAR) Indonesia dan saat ini di kelola oleh Jakarta Animal Aid Network (JAAN 2016).

Program rehabilitasi dan penyelamatan elang di pulau Kotok Besar terselenggara atas kerjasama antara Balai Taman Nasional Kepulauan Seribu, Balai Konservasi Sumber Daya Alam DKI Jakarta, dan Jakarta Animal Aid Network tertuang dalam perjanjian kerjasama Nomor: PKS/150/IVK.9/MoU/2016, Nomor: PKS.151/BTNKpS1/2016, Nomor: 01/JAAN/MoU/II/2016, dalam rangka program rehabilitasi dan penyelamatan elang bondol serta elang lainnya di Pulau Kotok Taman Nasional Kepulauan Seribu. Pada awal kegiatan program rehabilitasi JAAN hanya fokus pada jenis elang bondol, tapi pada perkembangannya pada tahun 2007 menerima elang-laut perutputih (Haliastus leucogaster). Sejak tahun 2005, ada 69 elang bondol dan 18 elang-laut perut-putih yang berhasil diselamatkan oleh JAAN, yang berhasil dilepasliarkan adalah 73 ekor yang terdiri dari 57 elang bondol dan 16 elang-laut perut-putih (JAAN 2016).

\section{Identifikasi Masalah}

1. Bagaimana sejarah program penyelamatan dan rehabilitasi elang bondol di pulau kotok?

2. Bagaimana upaya konservasi dan rehabilitasi elang bondol?

3. Bagaimana kondisi elang bondol di Pulau Kotok saat ini? 


\section{Tujuan penelitian}

1. Mengetahui sejarah program penyelamatan dan rehabilitasi elang di pulau kotok?

2. Mengetahui upaya konservasi dan rehabilitasi elang bondol ?

3. Menjelaskan kondisi elang bondol di Pulau Kotok saat ini?

\section{Metode Penelitian \\ Metode}

Metode pendekatan yang dipakai adalah metode Deskriptif Analitik yakni mengkaji suatu fenomena dengan menggambarkan apa adanya dari data-data yang telah terkumpul guna menjawab suatu permasalahan dan menemukan kesimpulan yang bersifat umum. Metode pengumpulan data dilakukan langsung pada obyek - obyek penelitian yang ada hubungannya dengan masalah yang diteliti. Sebagian sumber informasi akan digali infomasi yang terpercaya guna mendapatkan penelitian yang teoritis berupa pendapat pihak lain yang berwenang.

\section{Objek Penelitian}

Objek dari penelitian ini ialah elang bondol di pulau kotok, Taman Nasional Kepulauan Seribu.

\section{Teknik pengumpulan data}

Teknik pengumpulan data merupakan teknik atau cara yang dilakukan untuk mengumpulkan data. Metode pengumpulan data yang digunakan meliputi:

\section{Wawancara}

Wawancara dilakukan kepada penjaga kandang elang pulau kotok. Wawancaradilakukan dengan menanyakan seputar elang bondol (kegiatan rehabilitasi dan perawatan elang bondol, kesehatan elang bondol, dan perilaku elang bondol).

2. Studi Pustaka

Studi pustaka dilakukan untuk mengumpulkan sejarah, dasar hukum pelaksanaan kegiatan, dan .data terkait elang bondol, kegiatan rehabilitasi dan perawatannya diambil dari berbagai sumber seperti dokumen, laporan, buku, jurnal, dan media elektronik.

3. Observasi Lapang
Observasi lapang dilakukan di lokasi dengan cara pengamatan langsung terhadap objek kajian.

Menurut penjaga pusat rehabilitasi elang, ada 4 jenis elang yang terdapat di Kepulauan Seribu, yaitu elang bondol, elang laut, elang kepala abu, dan elang piran. Namun elang piran saat ini sudah sangat jarang terlihat. Saat ini terdapat 11 elang bondol yang sedang direhabilitasi di pusat rehabilitasi elang bondol pulau kotok.

Secara umum elang bondol (Haliastur indus) mempunyai karakteristik tubuh berwarna putih dan coklat pirang. Spesies ini termasuk elang yang berukuran sedang, dengan panjang tubuh sekitar $45-50 \mathrm{~cm}$, rentang sayap bisa mencapai $110-125 \mathrm{~cm}$, berat tubuh sekitar $320-670$ gram, serta panjang ekor berkisar $18-22 \mathrm{~cm}$. Pada individu dewasa kepala, leher dan dadanya memiliki bulu berwarna putih dan garis-garis kelabu. Bulu punggung, sayap, perut dan ekornya berwarna coklat kemerahan.

Elang bondol di mancanegara dikenal dengan nama Brahminy kite karena ketika terbang bentuknya mirip dengan layanglayang. Di Australia elang bondol dikenal dengan nama Red-backed Sea-eagle. Spesies ini pertama kali dideskripsikan oleh naturalis Belanda bernama Pieter Boddaert tahun 1783.

\section{Klasifikasi dan Sistematika Elang Bondol adalah sebagai berikut :}

Kingdom : Animalia

Phyllum : Chordata

Class : Aves

Ordo : Accipitriformes

Famili : Accipitridae

Genus : Haliastur

Spesies : Haliastur indus Boddaert, 1783

Subspesies : Haliastur indus indus

Boddaert, 1783

Haliastur indus intermedius Blyth, 1865

Haliastur indus girrenera Vieillot, 1822

Haliastur indus flavirostris Condon dan Amandon, 1954 


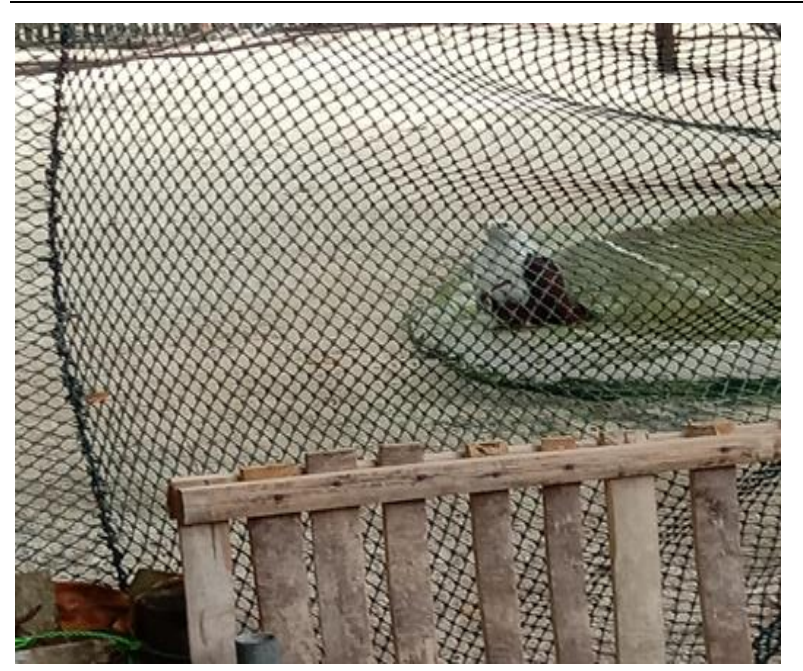

(Sumber :Danica, 2018)

Gambar 1. Elang Bondol

Fasilitas yang terdapat di pusat rehabilitasi elang bondol Pulau Kotok yaitu terdiri dari kandang isolasi, kandang sanctuary, kandang sosialisasi dan kandang pra release. Kandang isolasi berfungsi untuk memonitoring elang bondol hasil sitaan selama satu atau tiga bulan. Kandang sanctuary berfungsi untuk menampung dan memonitoring elang bondol yang kondisinya sudah sangat parah dan tidak memungkinkan untuk dilepasliarkan lagi. Lamanya waktu monitoring di kandang sanctuary yaitu satu atau tiga bulan. Kemudian jika ada perkembangan, elang bondol selanjutnya masuk ke kandang sosialisasi. Kandang prarelease berfungsi untuk melatih dan membiasakan kemampuan berburu elang bondol sebelum dilepasliarkan. Kandang prarelease ini merupakan yang paling menentukan apakah elang bondol siap dilepasliarkan atau tidak. Tempat untuk melepasliarkan elang bondol biasanya di pulau kosong seperti di Kalimantan, Lampung, dan Cilacap.

Pada kandang sanctuary terdapat dua kandang, yang masing-masing berisikan dua elang bondol pada setiap kandang dan satu elang bondol yang katarak ditempatkan pada kandang belakang. Elang bondol yang katarak tersebut sengaja dipisahkan dari elang bondol lainnya karena dikhawatirkan akan kalah saing saat berebut makanan dengan elang bondol lainnya. "Sanctuary tuh istilahnya panti jompo, jadi elang yang udah ngga layak dilepasliarkan karena sayap primernya dipatahkan yang tujuannya untuk display. Jadi elangnya udah ngga bisa terbang," ungkap Benvika kepada Warta Kota di Pulau Kotok, Kepulauan Seribu, Selasa (19/3). Perawatan dan pemeliharaan yang baik secara berkala untuk elang bondol di Pulau Kotok mampu membantu pelestariannya.

Fasilitas pusat rehabilitasi elang di Pulau Kotok sudah memenuhi kriteria sebagai pusat rehabilitasi satwa, tetapi perlu penambahan fasilitas kesehatan berupa klinik sehingga elang sakit dapat segera ditangani. Berdasarkan Peraturan Menteri Kehutanan Nomor P.31/Menhut-II/2012 tentang Lembaga Konservasi, pusat penyelamatan rehabilitasi memiliki fasilitas kesehatan, sekurangkurangnya terdiri atas: karantina, klinik; dan koleksi obat (KLHK 2012).

Elang bondol diberikan makan setiap jam 4 pagi. Hal itu dikarenakan agar elang tidak melihat penjaga menaruh makanan di kandangnya, sehingga elang tidak terbiasa menunggu makanan dari penjaga dan ketika dilepas kembali ke alam liar, elang tersebut tidak menjadi manja. Pakan untuk elang biasanya ikan betok dan ikan lape, setiap sekali makan diberikan 4 buah ikan. Pemberian pakan untuk elang yang direhabilitasi sama seperti elang biasa, yaitu 3 hari 2 kali makan, yaitu pada hari pertama dan kedua diberikan pakan kemudian pada hari ketiga tidak diberikan pakan. Tujuannya agar elang terbiasa makan tidak berlebihan sehingga saat dilepasliarkan mampu bertahan hidup.

Penjaga di pusat rehabilitasi Pulau Kotok biasa mengecek kesehatan elang setiap tiga bulan sekali. Biasanya yang melakukan pengecekan tiga orang penjaga. Hal yang dicek antara lain sayap, kaki, dan chip. Pengecekan tersebut rutin dilakukan untuk melihat perkembangan dari elang yang direhabilitasi dan mencegah menularnya penyakit.

Hal yang menarik mengenai elang bondol yaitu ia kerap bersuara ketika banyak orang atau merasa terdapat gangguan. Elang bondol pada asalnya tidak bersuara, namun ketika merasa terganggu atau setres maka elang bondol akan mengeluarkan suara nyaring. Hal lain yang dilakukan saat elang bondol stress yaitu menggelantung, ataupun bisa menyerang.

Sampai saat ini elang bondol belum bisa dibedakan jenis kelaminnya karena elang 
bondol termasuk burung monomorfik, yakni susah dibedakan jenis kelaminnya secara kasat mata karena memiliki morfologi yang sama. Padahal penentuan jenis kelamin memberikan informasi penting mengenai strategi perkembangbiakan dan manajemen konservasi (Helander et al. 2007; Garcia et al. 2009). Penentuan jenis kelamin secara pasti hanya dapat dilakukan dengan cara pengecekan DNA. Namun hal tersebut tidak dilakukan karena biaya pengecekan sangat mahal. Pengelola menggunakan metode dimorfisme seksual untuk menentukan jenis kelamin elang bondol, dimana ukuran tubuh raptor betina biasanya lebih besar dibandingkan jantan (Ferguson-lees dan Christie 2001).

Elang bondol yang direhabilitasi berasal dari penyerahan masyarakat, serta pemindahan dari Pusat Penyelamatan Satwa (PPS) di wilayah Jakarta, Jawa Barat dan sekitarnya. Kondisi sebagian besar elang bondol dinyatakan tidak dilayak untuk dilepasliarkan sehingga ditempatkan di kandang sanctuary. Menurut penjaga kandang elang, tidak semua elang hasil sitaan masih bisa direhabilitasi. Hal itu dikarenakan banyaknya elang bondol hasil sitaan yang kondisinya sudah cacat, seperti sayapnya patah, bulu primernya sudah tercabut, matanya katarak, dan lain sebagainya.

Elang bondol yang diserahkan ke pusat rehabilitasi pada umumnya mengalami perubahan perilaku alami dan kondisi kesehatan yang tidak baik. Hal ini disebabkan elang yang dipelihara manusia diperlakukan tidak baik, seperti kondisi kandang yang tidak layak dan pemberian pakan yang tidak sesuai. Menurut Castellanos (2005) menyatakan satwa yang berada dalam kurungan akan mengalami perubahan perilaku menjadi jinak dan kehilangan ketakutan terhadap manusia.

Menurut Dijk (2005) menyatakan bahwa faktor waktu merupakan salah satu faktor yang penting untuk diperhatikan dalam program rehabilitasi. Jika elang terlalu lama berada di pusat rehabilitasi dikhawatirkan sifat alaminya hilang karena sering terjadi kontak dengan manusia. Elang sebaiknya tidak terlalu lama berada di pusat rehabilitasi, namun untuk melatih perilaku alami untuk memiliki kemampuan bertahan hidup dialam diperlukan waktu yang cukup lama. Selain itu semakin lama direhabilitasi maka biaya yang dikeluarkan juga semakin besar.

Rehabilitasi elang tidak semudah yang kita bayangkan, karena dalam proses rehabilitasi tidak semua elang tersebut dapat dilepas liarkan kembali. Kondisi sayap beberapa elang tersebut mungkin sudah ada yang sudah rusak ataupun patah, sehingga tidak dapat terbang jauh. Selain itu, beberapa elang hasil sitaan yang direhabilitasi memiliki kebiasaan yang berbeda karena lebih sering dirawat di rumah hingga tidak memiiki insting alami untuk bertahan hidup di alam liar.

\section{SIMPULAN}

Elang bondol yang merupakan maskot kota DKI Jakarta saat ini sedang berada diambang kepunahan. Rehabilitasi elang tidak semudah yang kita bayangkan, karena dalam proses rehabilitasi tidak semua elang tersebut dapat dilepas liarkan kembali. Sudah seharusnya kita menumbuhkan kesadaran dan pemahaman akan pentingnya menjaga pelestarian satwa Indonesia, salah satuya elang bondol.

\section{DAFTAR PUSTAKA}

Alamendah. (2011). Elang Bondol Maskot Kota Jakarta yang Makin Langka. Tersedia online https://alamendah.org/2012/04/16/elangbondol-maskot-kota-jakarta-yang-makinlangka/ Diakses pada 23 Desember 2018.

Antaranews. (2007). Taman Nasional Pulau Seribu Lepas Delapan Elang Bondol. Tersedia online https://www.antaranews.com/berita/61983 /taman-nasional-pulau-seribu-lepasdelapan-elang-bondol. Diakses pada 7 Januari 2019.

Beritajakarta. (2017). Tempat Konservasi Elang Bondol di Pulau Kotok akan Ditata. 2017. Tersedia Online : http://m.beritajakarta.id/read/40282/tempa t-konservasi-elang-bondol-di-pulaukotok-akan-ditata. Diakses pada 7 Januari 2019. 
Beritajakarta. (2018). Mengintip Rehabilitasi dan Konservasi Elang Bondol di Pulau Kotok Bersama Pertamina Eco Camp. Tersedia online http://m.beritajakarta.id/read/40282/tempa t-konservasi-elang-bondol-di-pulaukotok-akan-ditata. Diakses pada 7 Januari 2019.

Biodiversitywarriors. (2014). Pusat Rehabilitasi Elang di Kepulauan Seribu. Tersedia online : https://www.biodiversitywarriors.org/pusa t-rehabilitasi-elang-di-kepulauanseribu.html. Diakses pada 23 Desember 2018.

Centrapola. (2018). Open Trip To Pulau Kotok - Fun Camp \& Konservasi Elang BondolEvent. Tersedia online : http://www.centropala.org/index.php/2018 /05/19/kpacekakpala-cinta-alam-jugacinta-fauna-liburan-ke-pulau-kotoksekaligus-menyelamatkan-elang-bondol/. Diakses pada 7 Januari 2019.

Gunadarma. (2010). Elang Bondol Di Kepulauan Seribu Terancam. Tersedia Online Http://Wartawarga.Gunadarma.Ac.Id/201 0/01/Elang-Bondol-Di-Kepulauan-SeribuTerancam/. Diakses Pada 7 Januari 2019.

Literasipublik. (2017). Konservasi Elang Bondol di Pulau Kotok. Tersedia Online : https://www.literasipublik.com/konservasi -penyelamatan-elang-bondol. Diakses pada 5 Januari 2019.

Mediaindonesia. (2018). Peduli Nasib Elang Bondol, Pertamina Bantu Konservasi di Kepulauan Seribu. Tersedia Online : http://mediaindonesia.com/read/detail/190 899-peduli-nasib-elang-bondol-pertaminabantu-konservasi-di-kepulauan-seribu. Diakses pada 23 Desember 2018.

Nationalgeographic. (2018). Pertamina Ecocamp dan Pelepasliaran Elang Bondol di Kepulauan Seribu. 2018. Tersedia online http://nationalgeographic.grid.id/read/133 09895/pertamina-ecocamp-danpelepasliaran-elang-bondol-di-kepulauanseribu? page $=2$. Diakses pada 23 Desember 2018.

Negerisendiri. (2018). Elang Bondol, Maskot Jakarta yang Nyaris Punah. Tersedia online

http://blog.negerisendiri.com/blogpage.ph p?judul=320. Diakses pada 7 Januari 2019.

Ohelterskelter. (2018). Menjenguk Elang Bondol, sang Maskot Jakarta, di Pulau Kotok. Tersedia Online : http://ohelterskelter.com/menjengukelang-bondol-di-pulau-kotok/ Diakses pada 5 Januari 2019.

Pesonakepulauanseribu.

(2013). [EnjoyJakarta] Cintaku Berlabuh di Kepulauan Seribu. Tersedia online : https://pesonakepulauanseribu.wordpress. com/tag/pulau-kotok/. Diakses pada 8 Januari 2019.

Pulauseribu. (2018). Pemkab Jakarta Kepulauan Seribu Dukung Pelestarian Elang Bondol. Tersedia online : http://pulauseribu.jakarta.go.id/web/v3/?p $=$ berita\&id=4833. Diakses pada 7 Januari 2019.

Rachmania, Kartika Nurul. (2015). Pengelolaan Perawatan, Rehabilitasi, Dan Penilaian Kesejahteraan Elang Di Pulau Kotok Besar, Jakarta. Departemen Konservasi Sumberdaya Hutan Dan Ekowisata Fakultas Kehutanan Institut Pertanian Bogor : Bogor.

Stemit. (2017). Bondol Eagle, Jakarta City Mascot (Bilingual). Tersedia online : https://steemit.com/elang/@amriadits/bon dol-eagle-jakarta-city-mascot-bilingual. Diakses pada 7 Januari 2019.

Tribunews. (2018). Menengok Elang Bondol yang Nyaris Punah di Pulau Kotok Kepulauan Seribu. Tersedia Online : 
http://wartakota.tribunnews.com/2018/03/21/ menengok-elang-bondol-yang-nyarispunah-di-pulau-kotok. Diakses Pada 5 Januari 2019.

Ulumiyah, Nurul. (2018). Faktor-Faktor Penentu Keberhasilan Pelepasliaran Elang Bondol (Haliastur Indus Boddaert, 1783) Di Taman Nasional Kepulauan Seribu. Bogor. Sekolah Pascasarjana Institut Pertanian Bogor : Bogor. Diakses pada 21 Desember 2018.
Viewindonesia. (2013). Melihat Rehabilitasi Elang di Pulau Kotok Besar. Tersedia online http://viewindonesia.com/index.php/travel -destination/66-melihat-rehabilitasi-elangdi-pulau-kotok-besar. Diakses pada 7 Januari 2019.

Wikipedia. (2018). Pulau Kotok Besar. Tersedia online https://id.m.wikipedia.org/wiki/Pulau_Kot ok_Besar. Diakses pada 5 Januari 2019. 